\title{
IMPLICATIONS OF THE FAILURE TO PAY THE REQUIRED ELECTORAL DEPOSIT IN SOUTH AFRICA: ANALYSING NATIONAL FREEDOM PARTY V ELECTORAL COMMISSION AND ANOTHER
}

\begin{abstract}
Angelo Dube
Department of Public, Constitutional and International Law, University of South Africa, South Africa

The right to participate in elections is one of the cornerstones of any democratic country. This is true of South Africa's electoral process, which was put to the test in the case of National Freedom Party v Electoral Commission in 2016. To promote free and fair elections, certain safeguards must be put in place. These include notifying the Electoral Commission of an intention to participate in elections through the payment of a deposit on a specified date by the party intending to participate in elections, and the publication of an election timetable by the government. This research has found that once published, the Electoral Commission has no power to change the electoral timetable. The only remedy for a party that fails to comply with the electoral prescripts such as the payment of an electoral deposit lies under section 11(2)(a) of the South African Local Government: Municipal Electoral Act. Additionally, it found that the concept of free and fair elections takes into account the interests of all parties concerned, and not just that of the party that alleges unfairness stemming from the exclusion. Whilst the exclusion of a party can lead to the violation of certain fundamental rights, such as the right to regular free and fair elections, and the right to vote, it is important to note that this case clearly establishes the legal position that a party's failure to comply with the legal prescripts, will bar that political party from obtaining a remedy for exclusion.
\end{abstract}

KEY WORDS: ELECTORAL COMMISSION, ELECTORAL TIMETABLE, FREE AND FAIR ELECTIONS, CONDONATION, NON-COMPLIANCE.

\section{Background}

On 5 July 2016, the South African Electoral Court delivered a judgment in a case involving the National Freedom Party (NFP) and the Electoral Commission, with the Inkatha Freedom Party (IFP) intervening. Inkatha Freedom Party is a registered political party which was also contesting elections in the same wards as the NFP. It had complied with the legal requirements and had fully paid its deposit on time. This was in the case of National Freedom Party $v$ Electoral Commission (Case No oo6/20I6 EC; [2016] ZAEC 2) (NFP No.I). The matter was heard on an urgent basis, and dealt with the question of whether the Electoral Commission had the power to vary the electoral timetable under section II(2)(b) of the South African Local Government: Municipal Electoral Act 27 of 2000 as 
requested by the NFP after it failed to pay the required deposit by 2 July 2016 . This section deals with the election timetable and it states that, 'the commission may, by notice as required in subsection (I)(b), amend the timetable if (a) it considers it necessary for a free and fair election; or (b) the voting day is postponed'.

This matter (NFP No.I), in which the IFP was the only other political party cited, was later followed by a similar application in which six other political parties were cited, that is the case of National Freedom Party $v$ Electoral Commission Case No ori/2016; [2016] ZAEC 3 (NFP No.2).

During proceedings, the NFP indicated that it sought relief that it be granted leave to appeal against a decision of the Electoral Commission in which it refused to condone the late payment on 22 July 2016 of the electoral deposit as required by law. Further, that the electoral timetable be varied to allow the payment of the deposit by 22 July. The NFP argued that the above issue was critical to promote free and fair elections. Basically, the gravamen of the NFP's application was that the issue be referred back to the Commission in order for it to consider whether the elections would be free and fair in light of the NFP's exclusion, as well as to allow the NFP to participate in the August municipal elections (para I2). However, the issue was not clearly framed, and the court had to deal with this impediment as counsel shifted back and forth between the matter being an appeal and it being a review. Eventually, after much deliberation, counsel for the NFP presented the matter as an appeal/review.

When the court heard the matter, it proceeded to hear argument before taking a decision whether to grant such leave or not (para 9).

The court held that, there is no provision which enables the court to grant condonation for the non-compliance with the provision of the relevant legislation nor is there any provision for the Commission to grant condonation for anyone regarding that person's non-compliance with the law. This means that, once the election timetable is published, it becomes subordinate legislation with full force and effect and becomes binding for all parties. The election timetable which is required in terms of Section II of the Local Governance: Municipal Electoral act 27 of 2000 becomes a law of general application to all and does not provide for condonation for non-compliance therewith. Notably the court emphasised that, there is no sanction for non-compliance other than placing oneself outside the contest due to non-compliance.

The court then turned its focus to the main issue of the case which was to determine whether the exclusion of the NFP party from participating in the election would render the election process unfair and not free. In addressing this issue, the court opined that the determination of whether an election was free and fair or not, commences when it is first called (para 29). Hence from the date on which the election is first announced, all prospective participants are required to observe the prescripts as laid down by the government or the electoral commission. Individuals or parties who fail to comply with these electoral prescripts run the risk of paying the ultimate price, which is exclusion from the electoral contest. The court further stated that those parties, such as the IFP, which complied with the prescripts acted fairly. As such, they were entitled to complain 
of an unfair election should non-compliant candidates and parties (such as the NFP) be allowed to join in the process despite their failure to comply with the prescripts. The court went on to state that the inclusion of the NFP would be unfair vis-à-vis those participants who acted lawfully. It added that the election timetable is a regulatory mechanism to ensure free and fair elections. As such, it could not be changed to suit individuals for that would render the timetable an inefficient electoral tool (para 30 ).

The court concluded that the NFP failed to comply with its obligation to pay the electoral deposit, resulting in its failure to utilise the process available to it in order to participate in the elections in those wards where it intended to do so. In other words, its looming nonparticipation in the elections was nothing other than the consequence of its own failures (para 39). In conclusion, the court noted that in the case at hand, to refer the matter back to the Commission would be to require it to consider the inclusion of the NFP in the election process despite the party's failure to comply with the election timetable. The Electoral Court emphasised that, the Commission has no power to make such a decision hence this would be a futile move (para 40).

\section{Was there a decision against which an appeal could be brought?}

The court had to first deal with the question whether a decision existed against which the NFP could lodge its appeal (para 4I). Wepener J opined that the circumstances in which an appeal can be noted are found in section 20(2)(a) of the Electoral Act. The provision states that, 'the Electoral Court may hear and determine an appeal against any decision of the Commission only in so far as such decision relates to the interpretation of any law or any other matter for which an appeal is provided by law'.

In para I5 the court had regard to the instances in which it could hear an appeal. The court was of the view that in the absence of evidence that the Commission interpreted any law, an appeal could not flow from what was perceived by the NFP to be a decision of the Commission. The Electoral Act in section 30(4) limits appeals to instances where a decision has been taken by the Commission in relation to the nomination of a candidate. It also allows an appeal against a decision of the Commission regarding the final outcome of an election in section 55(5). None of these two circumstances related to the NFP application.

Turning to the question of whether the matter could be regarded as a review, the court emphasised the need for a prior decision to have been taken by the Commission, against which a review could then be sought (para 22). The record before the court did not allude to any such decision, and as a result, the court held that the Commission's 'decision' could not be attacked under review as well. However, due to the narrow scope of the foregoing enquiry, the court elected to assume, without deciding, that the Commission did take a decision (para 25). However, in the court's view, that decision was no more than a recital of the Commission's belief that it had no power to condone late payments of the electoral deposit. In other words, it was not a decision from which an appeal or review could flow. 


\section{Constitutional implications of the decision}

It is clear that the right to vote is central to an open and democratic society, it is one of the important rights in the bill of rights (De Vos, 2003: 9). It forms part of a cluster of rights that are central to providing a check on the power of the government to infringe on particular realms of individual autonomy (Douglas, 2008: I47). The value of universal adult suffrage, as enshrined in section $\mathrm{I}$ of the South African Constitution demands that regular elections be held, in which political parties are able to contest for political power. This section states that, 'the Republic of South Africa is one, sovereign, democratic state founded on the following values: (d) universal adult suffrage, a national common voters roll, regular elections and a multi-party system of democratic government, to ensure accountability, responsiveness and openness'.

Sachs J in August and Another $v$ Electoral Commission [1999] ZACC 3 (para 17) gave the view that:

Universal adult suffrage on a common voter's role is one of the foundational values of our entire constitutional order. The achievement of the franchise has historically been important both for the acquisition of the rights of full and effective citizenship by all South Africans regardless of race, and for the accomplishment of an all-embracing nationhood. The universality of the franchise is important not only for nationhood and democracy. The vote of each and every citizen is a badge of dignity and personhood. Quite literally, it says that everybody counts. In a country of great disparities of wealth and power it declares that whoever we are, whether rich or poor, exalted or disgraced, we all belong to the same democratic South African Nation; that our destinies are intertwined in a single interactive polity. Rights may not be limited without justification and legislation dealing with the franchise must be interpreted iffavour of enfranchisement rather than disenfranchisement.

In addition to the above quotation, the court in the Electoral Commission $v$ Inkatha Freedom Party CCT 33/II [20II] ZACC I6 held that, these foundational values require courts and the Commission to construe the electoral statutes in a manner that promotes enfranchisement rather than disenfranchisement and participation rather than exclusion (para 37). This stimulates good governance, ensures that dictatorial tendencies are kept at bay and augments overall public participation in democratic processes. The Electoral Commission plays a substantial role in that regard, as the institution imbued with power to ensure that all these ideals translate into reality. This is an important consideration given South Africa's history of disenfranchisement of black voters.

Sachs $J$ in August $v$ Electoral Commission emphasised 'the right to vote by its very nature imposes positive obligations upon the legislature and the executive' (para I6). These obligations include the creation of systems and institutions to make the realisation of this right a reality for all citizens. This is aptly captured in Article 2I of the Universal Declaration of Human Rights, which underscores the integral role played by transparent and fair elections in participatory government. It is also in line with the right of every individual to determine their political status as per Article 20 of the African Charter on Human and Peoples' Rights, and to participate freely in the government of their country 
(Article I3). Further, Article 25 of the International Covenant on Civil and Political Rights also underscores this right, and calls for universal adult suffrage.

This means that the state, through its Electoral Commission must actively facilitate elections, and not be a mere spectator. Indeed, the Kenya High Court aptly put it in the case of Kituo Cha $v$ Independent Electoral and Boundaries Commission 2013 eKLR that it not envisaged that the state will be a passive actor, but it is expected to proactively ensure fundamental rights, such as the right to vote (para 9).

The Commission's positive acts include setting the election date as well as ensuring that a system of voting by secret ballot is in place to ensure the integrity of the voting process. The South African Constitution thus makes provision for free and fair elections through the establishment an oversight body, the Commission, to manage those elections. The Constitution requires the Commission to be an independent and impartial body, exercising the powers given to it by law, including ensuring that eligible voters are registered and eligible office bearers are voted for. This creation of a conducive environment accords with what Mathenjwa (2017: 184) terms as the confluence of the existence of the right to vote with positive contribution to the democratisation of government.

The NFP argued that a refusal to vary the electoral timetable, and to accept its late payment would jeopardise its chances of being voted into office. In other words, it would negatively impact on the party's political rights. Section 2 of the Local Government: Municipal Electoral Act 27 of 200 states that any person interpreting or applying this Act must:

a) do so in a manner that gives effect to the constitutional declarations, guarantees and responsibilities contained in the constitution; and

b) take into account any applicable Code.

In interpreting the above provision the Constitutional Court in the Electoral Commission $v$ Inkatha Freedom Party noted that, section 2 of the Act requires the provisions of the Act to be construed in a manner that gives effect to the right 'to vote in elections' and 'the right to stand for public office' as contained in section I9(3)(a) and (b) of the South African Constitution. As already stated above, this section confers political rights to 'every citizen', and the right to vote and be voted for to 'every adult citizen'. This raises the question of whether a juristic person such as the NFP can be regarded as a citizen as envisaged by section I9? Although this question was not raised in court, it is imperative to analyse it here.

Quite often the constitution employs the term 'everyone'. In instances where the provision addresses a prohibition, the terms 'no one' and 'no person' are often used; for example section I3 which provides that, 'no one may be subjected to slavery ...', and section 9(4) which provides that, 'no person may unfairly discriminate ... against anyone...'. These terms do not often present interpretation challenges when the claimant of the rights in question is a natural person. However, when the claimant is a juristic person, the wording of section 8(4) of the Constitution becomes pertinent. The provision stipulates that, 'A juristic person is entitled to the rights in the Bill of Rights to the extent required by the nature of the rights and the nature of that juristic person'. 
But if citizenship is understood in the context of the South African Citizenship Act 88 of I995, only natural persons can lay claim to it. However, juristic persons must be permitted to invoke the rights of a natural citizen to attack laws or conduct that violate the freedoms contained in the Constitution (Currie and de Waal, 2013: 464). What will determine the citizenship of a juristic person is its place of incorporation, in other words, the location of what may be called its nerve centre. In the case of the NFP, it is a juristic person incorporated in South Africa, operating nationally but mostly in the KwaZuluNatal Province and incorporated by South Africans to advance the political rights of fellow South Africans. All these factors would lead to the conclusion that the NFP is indeed a South African corporate citizen.

The NFP's argument, in essence, was that its exclusion would negate any chances of the elections being free and fair. This should be seen in light of section I9(2) of the Constitution, which provides that: 'Every citizen has the right to free, fair and regular elections for any legislative body established in terms of the Constitution'. It was not clear, in the papers before court, whether the NFP was lodging this complaint on its own behalf only, or on behalf of its members as well. Nevertheless, its main thrust was that the elections would not be free and fair in light of its exclusion. In other words, the NFP was trying to ensure its participation in the August 2016 elections. It suffices to say that it was litigating to redeem its own rights, as a party, to participate in free, fair and regular elections. It was asserting this right as a citizen, albeit a juristic one.

The right to vote normally accrues to a natural person (De Vos, 20I4: 325). The nature of the section 19(3) right to vote is such that it only accrues to adult citizens and as such juristic persons cannot lay claim to it. However, as provided for in section 8(4), a juristic person may also enjoy certain of the rights in the Bill of Rights depending on the nature of the right, and the nature of the juristic person. The right to vote is essentially a political right, which in most jurisdictions (including South Africa) is exercised through the instrumentality of political parties. It is political parties that put together campaign trails, supply candidate lists, and present manifestos to the electorate in a bid to garner votes. Whilst political parties do not vote, they still have an interest in the entire voting process. As such, the NFP could lay claim to the right to a free and fair elections, which is ordinarily enjoyed by natural citizens.

Although the right to vote is jealously guarded under the Constitution, the court in the Economic Freedom Fighters $v$ The President of the Republic of South Africa [2014] ZAGPPHC rog, noted that, "while foundational values as enshrined in the Constitution must supersede other considerations, this does not apply where there is a glaring disregard for rules and regulations' (para 22). The court was of the view that to do so, would be to act outside the framework of law, and would flout the principle of legality and the rule of law. It is our argument that the complete disregard of the electoral timetable by the NFP negatively impacts on the rule of law, and cannot be tolerated in an open and democratic society. The court played a fundamental role in explaining the meaning of free and fair elections in light of the possibility of changing the electoral timetable. According to the electoral court in NFP No.1, The electoral process as a whole must be free and fair. It must be free 
and fair for all parties and not advance the interest of one party only (para 3I). Notably the court emphasised that the provisions of section II(2)(a) of the Local Government: Municipal Elections Act as allowing the Commission to extend the timetable must be seen against this background (para 33). The power should be exercised in circumstances where it applies to all participants in the election equally, otherwise it will open the flood gates for ad hoc extensions of time which may lead to unfairness and is not sanctioned by the legal prescripts. Such ad hoc condonations run the risk of creating unfairness, or a reasonable apprehension of unfairness (Fowkes 20I6: 84). The Commission is thus required to rigorously adhere to the provisions of the electoral prescripts.

What can be gleaned from the foregoing is that while the foundational values contained in the Constitution must supersede other considerations, this position is not absolute. It is still incumbent on political parties and individuals to ensure that they follow the prescripts of the law. In the NFP's case, this included paying the deposit as per the deadlines stipulated in the electoral timetable. A party cannot deliberately disregard the electoral prescripts, knowing full well that doing so will lead to its exclusion, and then turn around and claim that such exclusion violates the values contained in the Constitution. In other words, such a self-inflicted exclusion cannot be held to be in conflict with the value of 'regular elections and a multi-party system of democratic government'; neither does it go against the constitutional right to free, fair and regular elections if it is the result of wrongdoing on the part of the political party being excluded. To hold otherwise would be to encourage anarchy and reversing the gains made thus far under the 1996 Constitution. There have been several other cases involving political rights in which the Commission rejected submissions by political parties for failure to comply with the electoral prescripts. In the case of Electoral Commission v Inkatha Freedom Party [20II] ZACC I6 (para 7), the dispute arose ahead of the $201 \mathrm{I}$ local government elections (para 2). According to the electoral timetable, relevant documentation to contest the election had to be submitted by no later than I70ohrs on 25 March 20II. The IFP wanted to contest in the upcoming elections but did not submit its election documentation relating to the Umzumbe local government elections at the local offices of the Commission in Umzumbe by the time and date stipulated in the timetable. Its request to submit the relevant documentation at the Commission's Durban Offices on 25 March was rejected by the Commission, as was a subsequent request in writing to file for the documentation after the deadline. On appeal to the Constitutional Court, the court had to deal with one main question, which was based on the ground that the provisions of sections I4 and I7 of the Local Government: Municipal Electoral Act, read with the election timetable, required the IFP to submit election documentation by no later than I70ohrs on 25 March 20II at the Commission's local representative in Umzumbe.

It was noted in court that the decision of the Commission was based on the ground of the strict provisions of sections I4 and I7 of the Local Government: Municipal Electoral Act, read with the election timetable. The Electoral Court placed much reliance on the decision of the court in African Christian Democratic Party (ACDP) [2006] ZACC I (para II), where the main question the court had to address was whether the provisions of sections I4 and I7 
relating to the payment of deposits are peremptory so as to prevent the Commission from providing an alternative location for payment.

In the ACDP case, the court held that 'there seems to be no central legislative purpose attached to precise place where in a province the relevant documentation is submitted to the Commission'. The court also opined that, the courts should favour an interpretation of the Act that promotes enfranchisement and participation over disenfranchisement (ACDP, para 23). It went on to hold that, of crucial relevance also is the underlying statutory purpose of section I4 and I7 which appears to be to ensure that candidates and political parties contesting elections declare their intentions to do so by a certain date and provide the Electoral Commission with the necessary information to enable them to organise the elections. The payment of the deposit is thus complementary to the key notification required for organising the elections, namely the notification of the intention to participate and the furnishing of details of candidates.

Turning to the Electoral Commission $v$ Inkatha Freedom Party case, the IFP stressed the importance of the right to vote, universal franchise, and multi-party democracy as foundational values, and argued that the Commission had a positive obligation to promote enfranchisement (para 23). Failure to abide by the electoral timetable affects the way the Commission performs its constitutional duty to ensure free and fair local government elections (Electoral Commission $v$ Inkatha Freedom Party, para 7).

In essence, the question before the court was whether the provisions of sections I4 and I7 were peremptory. Intimately connected to this question is the consideration of whether failure to follow the electoral prescripts will affect the way the Commission performs its constitutional duty to ensure free and fair local government elections. In other words, whether there is a discernible legislative purpose in requiring that the payment be made on time. Indeed the payment does serve a purpose. The payment of the deposit is complementary to the key notification required for organising elections namely, the notification of the intention to participate and the furnishing of details of candidates (Electoral Commission $v$ Inkatha Freedom Party, para 7). The deposit thus signifies serious intentions of the party or candidate to contests elections, as elections are costly for the state (Mathenjwa, 2017: 193). Although largely accepted as augmenting the democratic process, election deposits can work against smaller parties who may not afford to pay their deposit, and can severely limit the rights of their supporters to participate in elections (Hart, 2015: 77). It should be noted, however, that the NFP's failure to pay the deposit was not attributed to financial difficulties on its part.

Armed with this jurisprudence, the court in the NFP case saw now need to depart from the established principle that the dictates of sections $\mathrm{I} 4$ and $\mathrm{I} 7$ are peremptory. The court viewed the electoral timetable as a regulatory mechanism whose purpose was to ensure that elections were free and fair (para 30). In essence, the court wanted to restate the law on abiding by electoral timetables, and to put a stop to ad hoc challenges to the electoral law, and prevent whimsical applications for extensions of time.

However, what is lacking from the court's treatment of the subject is the question of what factors would constitute 'fairness to all parties' in the event of an application 
for the electoral timetable being varied. When one takes into account the unfortunate circumstances of the IFP in the case of Electoral Commission $v$ Inkatha Freedom Party, the need for judicial guidance in this regard is even more glaring. As indicated above, in this case, the IFP failed to deliver its party documents at the Umzumbe office of the Commission, and subsequently tried to lodge the same at the Durban offices instead. The failure resulted from a combination of recklessness on the part of the IFP, and bad weather that grounded a chartered helicopter which would have delivered the necessary documents at Umzumbe within the deadline. Despite these compelling circumstances, the Constitutional Court refused to find in favour of the IFP. This therefore leaves a gap in our electoral law, in respect of the circumstances in which the Commission would favourably determine an application for varying the electoral timetable.

\section{Conclusion}

From the above discussion, it is clear that the Commission has no power to change the electoral timetable. The only remedy for a party that fails to comply with the electoral prescripts such as the payment of an electoral deposit lies under section II(2)(a) of the Local Government: Municipal Electoral Act. This provision allows the Commission to vary the timetable provided it considers that doing so would be in the interests of free and fair elections; and also where the voting date has been postponed. In this case, the concept of free and fair elections takes into account the interests of all parties concerned, and not just the one party that alleges unfairness flowing from the exclusion. However, our case law has failed up to this point, to provide definitive guidance on what those specific interests are.

The exclusion of a party can lead to the violation of certain fundamental rights in the Constitution, such as the right to regular free and fair elections, and the right to vote. Although these rights are jealously guarded by our Constitution, it is of paramount importance to note that this case clearly establishes the legal position that a party's failure to comply with the legal prescripts, will bar that political party from obtaining a remedy for exclusion. This is because the court perceives those parties that complied as having acted fairly, and therefore entitled to complain of an unfair election should noncompliant parties be allowed to join the process despite their failure to comply. This case too, like similar before it, does not offer judicial guidance on what the exact factors are that would sway a court to indulge a party seeking such a remedy.

\section{References}

Currie I. \& De Waal, J. (20I3). The Bill of Rights Handbook 6th ed. Cape Town: Juta.

De Vos, P. (2004). South African prisoners' right to vote. CSPRI Research Paper No.3A.

De Vos, P. (2014). South African constitutional law in context. Cape Town: Oxford University Press.

Douglas, J. (2008). Is the right to vote really fundamental. Cornell Journal of Law and Public Policy Vol I8 (I) I43-20I.

Fowkes, J. (2016). Building the Constitution: The Practice of Constitutional Interpretation in Post-Apartheid South Africa. Cambridge: Cambridge University Press. 
Hart, K. (2015). Economy for and Against Democracy. New York: Berghahn.

Mathenjwa, J. (2017). Election deposit and democracy in developing countries: A comparative overview in selected Southern African Development Community Countries. Journal of African Elections Vol. I6 (I) $180-$ Ig8.

\section{Cases}

National Freedom Party $v$ Electoral Commission (Case No oo6/20r6 EC; [2016] ZAEC 2.

National Freedom Party v Electoral Commission Case No orr/2016; [2016] ZAEC 3.

August and Another $v$ Electoral Commission [I999] ZACC 3.

Economic Freedom Fighters $v$ The President of the Republic of South Africa [2014] ZAGPPHC rog.

African Christian Democratic Party (ACDP) [2006] ZACC I.

Kituo Cha $v$ Independent Electoral and Boundaries Commission 2013 eKLR

Electoral Commission of the Republic of South Africa $v$ Inkatha Freedom Party (CCT 33/II) [20II] ZACC I6; $201 I$ (9) BCLR 943 (CC) (Io May 20II).

\section{Legislation}

Constitution of South Africa No 108 of 1996.

South African Citizenship Act 88 of 1995 .

Local Government and Municipal Act 27 of 2000.

Universal Declaration of Human Rights 1948.

International Covenant on Civil and Political Rights I966.

African Charter on Human and Peoples Rights I98I. 